\title{
Diet, prey selection and their energetic relationship to reproduction in the tropical herring Herklotsichthys quadrimaculatus in Kiribati, Central Pacific
}

\author{
D. A. Milton, S. J. M. Blaber, N. J. F. Rawlinson \\ CSIRO Division of Fisheries, PO Box 120, Cleveland, Queensland 4163, Australia
}

\begin{abstract}
Herklotsichthys quadrimaculatus (gold-spot herring) is a short-lived tropical herring (maximum age 1 yr) that matures at $5 \mathrm{mo}$ and spawns continuously thereafter. It forms an important component of the tuna baitfish catches in Kiribati. Central Pacific, but fluctuates widely in numbers. We examined diet and prey selection in the field to determine the influence of diet on reproduction and to see whether fluctuations in spawning activity were related to changes in the diet or prey available. $H$. quadrimaculatus is a particulate-feeder that feeds mainly at night, actively selecting both larger high-calorie zooplankton taxa and larger individuals of other taxa. The composition of the diet varied over the 2 yr of the study in relation to variations in the abundance of the main zooplankton taxa and not in relation to spawning activity. Fish of both sexes approaching sexual maturity ate more highcalorie prey (Teleostei and Caridea) than younger fish. This shift in diet would have a selective advantage for short-lived species, enabling them to continue growing rapidly while developing gonads. The energy content of muscle, gonads, and liver was examined in female $H$. quadrimaculatus at all stages of gonad development. There was no difference in the tissues, which had a mean content of $22.7 \pm$ $0.3 \mathrm{~kJ} \mathrm{~g}^{-1} \mathrm{dry} w \mathrm{t}$. The energy content of the liver was positively related to the energy content of the gonads but not to the mean dietary energy intake. The mean energy content of the gonads and the mean daily energy intake were inversely related, probably due to the body cavity having a smaller capacity. The mean daily energy intake was not related to the interval between spawnings or to the proportion of recently spent fish. The mean energy costs of producing an average-sized batch of eggs during peak spawning were too high to be obtained only from surplus intake. Both the liver mass and energy content declined in spent fish, which suggests that energy stored in the liver was mobilized during periods of frequent spawning. These results are consistent with recent findings that the spawning frequency of temperate clupeids is related to the animal's nutritional status.
\end{abstract}

KEY WORDS: Diet · Prey selection · Herring

\section{INTRODUCTION}

Most clupeoids are multiple spawners with an extended breeding season each year (Blaxter \& Hunter 1982). Tropical species in particular spawn over many months (e.g. Sardinella spp.; Dayaratne \& Gjøsaeter 1986) or throughout the year (e.g. Encrasicholina sp., Spratelloides sp. and Herklotsichthys sp.; Milton \& Blaber 1991, Milton et al. 1994). Although these species breed continuously, spawning is more frequent when the monsoon arrives in spring and autumn (Milton \& Blaber 1991).
Spawning in temperate clupeoids was believed to be related to the timing of maximum plankton production: the fish spawned when there was most food for the larvae (Cushing 1967, 1975). However, for many species, spawning may be related to food availability (Smith \& Eppley 1982) or to the nutritional status of the adults (Townshend \& Wootton 1984, Aneer 1985, Rajasilta 1992). These species store surplus energy in the liver or muscle (usually as lipids) for later conversion into gonad tissue (Brett \& Groves 1979, Henderson et al. 1984). Seasonal changes in the lipid content and 
proximate composition of these temperate clupeoids are related to differences in feeding success rather than reproductive metabolism (Hardy \& Mackie 1969, Hayashi \& Takagi 1977, 1978, Linko et al. 1985. Henderson \& Almatar 1989). This suggests that the energy required for growth and reproduction can, under favourable conditions, be obtained from excess food energy intake (Hunter \& Leong 1981, Boggs 1991).

In tropical clupeoids that breed continuously, energy turnover should be more rapid than in related temperate species. This means that short-term fluctuations in food supply may directly affect their spawning frequency. Wright (1990) compared the proximate composition of the liver, muscle and gonads of the tropical anchovy Encrasicholina heterolobus at different stages of gonad development. He found no differences in the lipid content of these organs, so concluded that the energy required for reproduction was obtained from immediate energy intake. If this is true, the frequency of spawning should be related to both the quality and quantity of prey the animal eats.

Herring Herklotsichthys quadrimaculatus is a major component of tuna baitfish catches in the South Pacific (Lewis 1990). In Kiribati, catches fluctuate widely, both seasonally and annually (Rawlinson et al. 1992). This species lives up to 1 yr and breeds continuously after sexual maturity at 5 mo of age (Milton et al. 1993, 1994). It is mainly nocturnal and zooplanktivorous (Marichamy 1970, Williams \& Clarke 1983) but the methods of feeding are unknown. If $H$. quadrimaculatus feed in a density-dependent manner then fluctuations in abundance may be directly related to prey abundance.

The aims of this study were: (1) to examine the diet and prey selection of the tropical herring Herklotsichthys quadrimaculatus; (2) to assess the relationships between prey selection, dietary energy intake and reproductive energetics and (3) to test the hypothesis that spawning is directly related to dietary energy intake.

\section{METHODS AND MATERIALS}

Study sites. The 4 study sites in Kiribati (Abaiang, Butaritari, Tarawa and Abemema) (Fig. 1) were atolls having a typical ocean platform coral reef structure built up by scleractinian corals and coralline algae on a submerged mountain (A. Gilmour \& R. Colman unpubl. data). They consist of small islets lying on the eastern and southern sides of a lagoon with an open western side due to the prevailing easterly winds. Most lagoons typically have passages between the islets through which water is exchanged. Lagoons were mainly shallow (20 to $30 \mathrm{~m}$ deep), often with large areas of intertidal seagrass or sand on their eastern sides. Bottom topography of the deeper parts of the lagoon was generally smooth, with some coral outcrops. Our study sites were similar to those described by Hobson \& Chess (1978) in the Marshall Islands.

Sampling. Samples of up to 20 Herklotsichthys quadrimaculatus were collected each month at 1 or more of the 4 sites in Kiribati between August 1989 and May 1991. Where possible, they were collected from commercial catches by vessels that attract fish at night with underwater lights and encircle them with a smallmeshed 'bouke-ami' lift net (Kearney 1982). As $H$. quadrimaculatus forms large schools in shallow water during the day, samples were also obtained each month by beach seining and cast netting in shallow water during the day. Surface and bottom gill nets of 25 and $38 \mathrm{~mm}$ stretch mesh were also set in deeper water in an attempt to catch $H$. quadrimaculatus that might not have aggregated in the shallows. This sampling method was discontinued after 6 mo when no herring were caught. Gill netting was also done at night near the fishing vessels, but away from the influence of the underwater light, and the samples preserved separately.

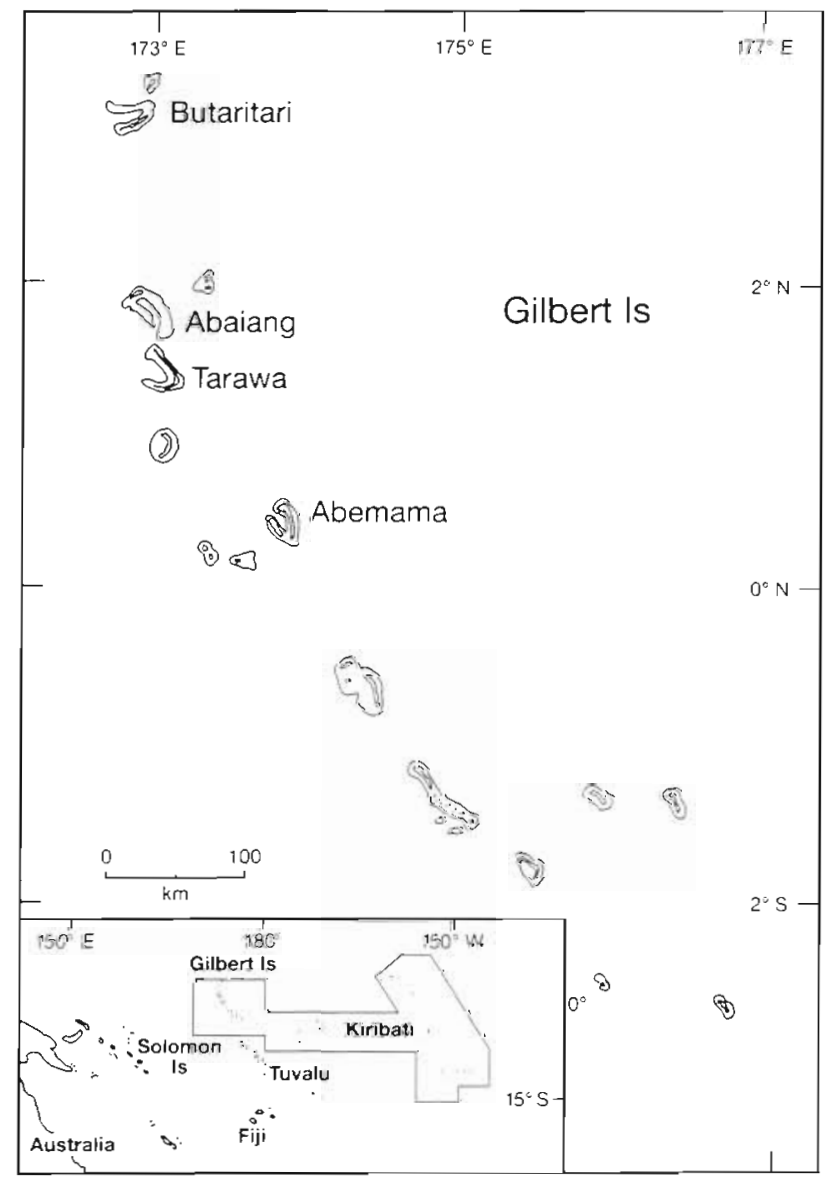

Fig. 1. Map of Kiribati showing the 4 study sites 
The fish were preserved in either $70 \%$ ethanol or $4 \%$ formaldehyde immediately on capture or frozen and analysed later in the laboratory. Fish preserved in $70 \%$ ethanol were used in dietary, ageing and reproductive studies (Milton et al, 1993, 1994). Those preserved in formaldehyde were used only in reproductive and energetic studies. Frozen fish were used in energetic studies as comparative material for the formaldehyde-fixed samples.

In the laboratory, the fish were measured (standard length in $\mathrm{mm}$ ), weighed ( $\pm 0.001 \mathrm{~g}$ ), sexed and their stomachs removed for examination under a light microscope. Prey taxa were identified at least to order (and to lower levels where possible) and counted. The total length and widest diameter of the smallest individual of each prey taxon (body only) were measured with an ocular micrometer and converted to $\mathrm{mm}( \pm 0.1)$. The smallest individual was chosen for comparison with gill-raker spacing of adult Herklotsichthys quadrimaculatus that previous studies had shown to be about $0.1 \mathrm{~mm}$ (D. A. Milton unpubl. data). The volume of each individual was estimated by assuming its shape approximated a cylinder as long and as wide as the prey. Each prey taxon was separated and dried at $60^{\circ} \mathrm{C}$ for at least $24 \mathrm{~h}$ to constant weight ( $\pm 0.01 \mathrm{mg}$ ).

The energy content of gonads, liver and muscle tissue of Herklotsichthys quadrimaculatus was determined in specimens with gonads in the 4 most advanced stages of development (as defined by Milton et al. 1994). A Parr Semimicro Bomb Calorimeter (Model 1411) was used. At least 5 females in each gonad development stage and 20 males of either fresh or formaldehyde-fixed material were examined. [Formaldehyde preserves most lipids (Baker 1966); other studies have found no difference in calorific content between fixed and fresh material (Whitfield 1980).] Tissue samples were dried at $60^{\circ} \mathrm{C}$ to a constant mass before bombing. The calorific contents of prey taxa were obtained from the literature. Where several values were reported for a particular prey group, we used either the mean of the group or the values of the closest taxa.

To examine zooplankton densities, and hence prey selection by Herklotsichthys quadrimaculatus, vertical plankton tows were made at night with a heavily weighted $0.5 \mathrm{~m}$ diameter net with a mesh size of $250 \mu \mathrm{m}$. On all occasions, at least $100 \mathrm{~m}^{3}$ was filtered per sample (14 to 50 hauls per sample). Hauls were made away from the influence of the baitlight before any herring were caught. Additional zooplankton samples were collected in shallow water close to the sites where the fish were caught by beach seines or cast nets during the day, and after dark at the same sites at least $1 \mathrm{~h}$ after baitfish sampling. All samples were preserved in $4 \%$ formaldehyde and transferred in the laboratory to 2-phenoxy-ethanol.
The zooplankton samples were split with a Folsom plankton splitter until a subjective count of 1000 to 2000 individuals was obtained (usually between 1/8 and $1 / 64)$. They were identified to the lowest possible taxon. On each sampling occasion, at least 100 individuals of each of the most common taxa found in the stomachs of the fish were separated, measured across their widest cross section, dried to a constant mass and weighed ( $\pm 0.01 \mathrm{mg}$ ). The average weight of an individual from these subsamples was used to calculate the relative contribution of each prey taxon to the weight of food in the stomachs of fish where the mass of that prey taxon was insufficient to be weighed separately. One-quarter of each plankton sample was separated and dried at $60^{\circ} \mathrm{C}$ to obtain an overall estimate of biomass.

Statistical analysis. The number and weight of prey consumed were compared to the prey available using the Wilcoxon signed rank test to assess temporal and site variation in diet. Eight taxonomic groups of zooplankton were the dominant taxa in all samples. The proportion of these taxa in the water column and in the diet of Herklotsichthys quadrimaculatus (by both weight and numbers) were compared separately. Many dietary studies use electivity indices to assess prey selectivity. However, Kohler \& Ney (1982) suggest that electivity determinations should be treated as relative rather than absolute measures of prey selection. The Wilcoxon test is free of the a priori statistical distribution problems of electivity indices and has been used in previous studies of tropical clupeid diets (Milton et al. 1990a).

The percentage biomass of major prey categories and their dimensions (width and volume) were compared between sites by analysis of variance after square root (percentage biomass) and logarithmic transformations (Sokal \& Rohlf 1981). The proportions of each of the 7 major prey taxa (Brachyura, Calanoida, Caridea, Hyperiidae, Lucifer, Polychaeta and Teleostei) in the diet of the fish at each site were compared separately by analysis of covariance with site, sex and time of day (day/night) as fixed effects and length as the covariate.

To examine the temporal pattern in reproductive energy allocation, we converted the mass of liver, gonad and muscle of Herklotsichthys quadrimaculatus (reported in Milton et al. 1994) to kilojoules. The energy content of the 3 tissues of female $H$. quadrimaculatus was compared using a 2-way ANOVA, with gonad stage and tissue type as fixed effects. For males, a 1-way ANOVA was used. Mean daily energy intake was estimated by converting the mass of each prey eaten at night to kilojoules and assuming 2 meals a night. During months when fish fed during the day, the energy content of these meals was added to the overall intake estimate for that month based on night feeding only. 


\section{RESULTS}

\section{Overall diet}

The diet of Herkiotsichthys quadrimaculatus did not differ greatly among the 4 sites in Kiribati (Table 1). $H$. quadrimaculatus is a nocturnal zooplanktivore (Fig. 2) that ate mainly crustacean zooplankton and teleost larvae at all sites (Table 1). The contribution to the diet by the 7 major prey types (by both weight and numbers) did not differ significantly among sites when the effects of size, sex and time of day were taken into account, the exception being at Butaritari, where fish ate more teleost larvae and less Caridea than at other sites $(p<0.05)$. Brachyuran megalopae were the most frequently taken prey at each site, although teleost larvae made the largest contribution by weight to the overall diet (Table 1). As these results indicated that $H$. quadrimaculatus diets were similar at each site, data from all sites were combined in all further comparisons of the effects of size and sex.

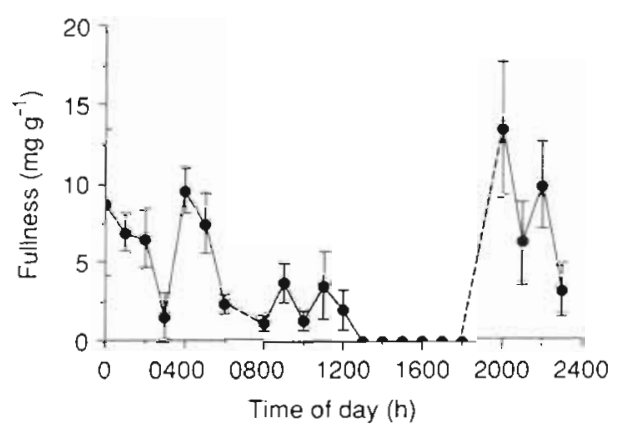

Fig. 2. Herklotsichthys quadrimaculatus. Diel variation in mean stomach fullness (mg dry wt of food $\mathrm{g}^{-1}$ dry wt of fish) (all sites combined). Bars: $\pm S E$. Dotted line joins points where no data were available

Herklotsichthys quadrimaculatus fed during both the day and night (Fig. 2), although in both years of the study they only fed during the day in September, October, March and April. Prey in the stomach were usually whole, and in the fish collected shortly after daylight.

Table 1. Herklotsichthys quadrimaculatus. Percentage frequency of occurrence (Fo), percent dry weight (Wt) and percent number (No) of all prey eaten by herring from 4 sites in Kiribati. Length range (in $\mathrm{mm}$ ) and number of each fish with prey ( $\mathrm{N}$ ) that were examined at each site are also shown

\begin{tabular}{|c|c|c|c|c|c|c|c|c|c|c|c|c|c|c|c|}
\hline \multirow{2}{*}{$\begin{array}{l}\text { Site: } \\
\text { Length range }(\mathrm{mm}): \\
\quad \mathrm{N} \text { : } \\
\text { Prey categories }\end{array}$} & \multicolumn{3}{|c|}{$\begin{array}{c}\text { Butaritari } \\
38-95 \\
203\end{array}$} & \multicolumn{3}{|c|}{$\begin{array}{c}\text { Abaiang } \\
34-95 \\
182\end{array}$} & \multicolumn{3}{|c|}{$\begin{array}{c}\text { Tarawa } \\
22-96 \\
147\end{array}$} & \multicolumn{3}{|c|}{$\begin{array}{c}\text { Abemama } \\
27-107 \\
117\end{array}$} & \multicolumn{3}{|c|}{$\begin{array}{c}\text { Overall } \\
22-107 \\
650\end{array}$} \\
\hline & Fo & $W t$ & No & Fo & Wt & No & Fo & $W t$ & No & Fo & Wt & No & Fo & Wt & No \\
\hline Diatomacae & 8.2 & 14.3 & 0.9 & - & - & - & - & - & - & - & - & - & 2.5 & 5.6 & 0.1 \\
\hline Polychaeta & 10.3 & 1.3 & 0.8 & 7.3 & 2.4 & 0.6 & 8.3 & 0.2 & 0.05 & 13.2 & 23.9 & 0.4 & 9.2 & 3.3 & 0.3 \\
\hline \multicolumn{16}{|l|}{ Mollusca } \\
\hline Heteropoda & 1.1 & $<0.01$ & $<0.01$ & - & - & - & - & - & - & - & - & - & 0.03 & 0.03 & 0.04 \\
\hline Pteropoda & - & - & - & 1.2 & 0.04 & $<0.01$ & 9.0 & 0.3 & 0.2 & - & - & - & 2.3 & 0.08 & 0.04 \\
\hline Bivalvia & 0.5 & $<0.01$ & $<0.01$ & 0.8 & $<0.01$ & $<0.01$ & 3.8 & 0.02 & 0.06 & 5.7 & 0.05 & 0.2 & 2.1 & 0.01 & 0.03 \\
\hline Other Gastropoda & 2.2 & 0.02 & 0.06 & 10.3 & 0.3 & 0.08 & 4.5 & 0.1 & 0.07 & 3.8 & 0.3 & 0.02 & 5.3 & 0.3 & 0.7 \\
\hline \multicolumn{16}{|l|}{ Crustacea } \\
\hline Calanoida & 41.3 & 9.5 & 52.4 & 57.0 & 4.5 & 20.9 & 63.2 & 12.1 & 55.9 & 34.9 & 37.6 & 93.7 & 49.2 & 12.2 & 67.8 \\
\hline Ostracoda & - & - & - & 3.6 & 0.05 & 0.2 & 8.3 & 0.1 & 0.1 & 6.6 & 0.1 & 0.04 & 9.7 & 0.2 & 0.2 \\
\hline Stomatopoda & 7.6 & 0.3 & 0.2 & 11.5 & 0.7 & 0.2 & 9.8 & 0.8 & 0.2 & 1.9 & 0.1 & 0.01 & 8.1 & 0.6 & 0.1 \\
\hline Mysidacea & 9.2 & 0.2 & 0.4 & 18.2 & 3.8 & 5.4 & 5.3 & 0.1 & 0.3 & - & - & - & 9.0 & 1.9 & 1.1 \\
\hline Isopoda & - & - & - & - & - & - & 0.8 & 0.01 & 0.02 & - & - & - & 0.2 & $<0.01$ & $<0.01$ \\
\hline Hyperiidae & 37.5 & 0.4 & 6.1 & 57.0 & 4.7 & 28.8 & 42.9 & 1.3 & 9.8 & 11.3 & 0.08 & 0.03 & 40.5 & 19 & 8.3 \\
\hline Other Amphipoda & 0.5 & 0.03 & 0.01 & - & - & - & 2.3 & 0.1 & 0.08 & 14.1 & 4.7 & 0.8 & 3.6 & 0.4 & 0.3 \\
\hline Penaeidae & 0.5 & 0.05 & $<0.01$ & 7.9 & 0.4 & 0.3 & 2.3 & 0.09 & 0.04 & 3.8 & 0.5 & 0.02 & 3.5 & 0.2 & 0.07 \\
\hline Lucifer & 10.3 & 1.2 & 3.9 & 20.0 & 3.4 & 8.8 & 14.3 & 3.7 & $\cdot 5.4$ & 16.0 & 6.8 & 0.9 & 15.1 & 3.0 & 3.3 \\
\hline Caridea & 28.8 & 2.1 & 2.7 & 60.0 & 37.6 & 13.7 & 66.9 & 41.2 & 13.7 & 24.5 & 4.0 & 0.3 & 47.5 & 19.9 & 5.0 \\
\hline Other Natantidea & 0.5 & 0.01 & 0.01 & - & - & - & - & - & - & 2.8 & 0.3 & 0.08 & 0.7 & 0.04 & 0.02 \\
\hline Thadassinidae & 0.5 & 0.04 & $<0.01$ & - & - & - & - & - & - & - & - & - & 0.2 & 0.02 & $<0.01$ \\
\hline Other Anomura & 9.9 & 0.2 & 3.7 & 9.7 & 0.4 & 2.0 & 1.5 & 0.01 & $<0.01$ & 5.7 & 0.1 & 0.02 & 6.9 & 0.2 & 0.9 \\
\hline Brachyura larvae & 69.0 & 6.1 & 18.3 & 76.4 & 8.2 & 11.3 & 85.0 & 13.4 & 11.7 & 49.1 & 7.9 & 1.2 & 72.7 & 8.7 & 7.2 \\
\hline Other Crustacea & 16.8 & 2.3 & 0.01 & 13.3 & 1.7 & 0.08 & 10.5 & 1.0 & 0.4 & 18.9 & 10.0 & 0.05 & 14.3 & 2.9 & 0.03 \\
\hline $\begin{array}{l}\text { Unidentified } \\
\text { Crustacea }\end{array}$ & - & - & - & 3.0 & 1.5 & 0.9 & - & - & - & 2.8 & 2.1 & 1.6 & 3.8 & 0.7 & 1.3 \\
\hline \multicolumn{16}{|l|}{ Pisces } \\
\hline Teleostei larvae & 67.4 & 57.5 & 11.2 & 45.5 & 32.6 & 7.7 & 39.8 & 25.7 & 1.9 & 9.4 & 1.6 & 0.02 & 46.2 & 37.6 & 3.2 \\
\hline Teleostei eggs & 0.5 & 0.01 & 0.05 & - & - & - & 6.8 & 0.1 & 0.09 & - & - & - & 1.6 & 0.04 & 0.04 \\
\hline
\end{tabular}


Table 2. Herklotsichthys quadrimaculatus. Percentage frequency of occurrence (Fo), percent dry weight (Wt) and percent number ( $\mathrm{No}$ ) of all prey eaten by herring from all sites in Kiribati during the day and night. N: number of fish examined

\begin{tabular}{|c|c|c|c|c|c|c|}
\hline & \multicolumn{3}{|c|}{$\begin{array}{c}\text { Night } \\
(20: 00-06: 30 h)\end{array}$} & \multicolumn{3}{|c|}{$\begin{array}{c}\text { Day } \\
(07: 00-18: 00 \mathrm{~h})\end{array}$} \\
\hline & & \multirow{2}{*}{\multicolumn{2}{|c|}{$\begin{array}{l}451 \\
15.5\end{array}$}} & \multirow{2}{*}{\multicolumn{3}{|c|}{$\begin{array}{l}603 \\
67.0\end{array}$}} \\
\hline \multicolumn{2}{|c|}{ Proportion empty (\%): } & & & & & \\
\hline Prey categories & Fo & $W t$ & No & Fo & $\mathrm{Wt}$ & No \\
\hline Diatomacae & - & - & - & 7.5 & 24.3 & - \\
\hline Polychaeta & 10.0 & 1.7 & 0.4 & 9.0 & 8.4 & 0.3 \\
\hline \multicolumn{7}{|l|}{ Mollusca } \\
\hline Heteropoda & 0.5 & $<0.01$ & $<0.01$ & 0.5 & 0.1 & $<0.01$ \\
\hline Pteropoda & 1.6 & 0.06 & 0.02 & 4.0 & 0.1 & 0.05 \\
\hline Bivalvia & 1.3 & $<0.01$ & 0.02 & 4.0 & 0.04 & 0.05 \\
\hline Other Gastropoda & 5.8 & 0.3 & 1.5 & 4.5 & 0.4 & 0.2 \\
\hline \multicolumn{7}{|l|}{ Crustacea } \\
\hline Calanoida & 52.2 & 7.8 & 36.7 & 47.7 & 27.3 & 94.1 \\
\hline Ostracoda & 13.1 & 0.2 & 0.4 & 4.0 & 0.08 & 0.05 \\
\hline Stomatopoda & 11.8 & 0.7 & 0.2 & 2.0 & 0.1 & $<0.01$ \\
\hline Mysidacea & 13.9 & 1.6 & 2.4 & 12.1 & 2.7 & 1.0 \\
\hline Isopoda & 0.3 & $<0.01$ & $<0.01$ & - & - & - \\
\hline Hyperiidae & 58.8 & 2.5 & 18.7 & 5.5 & 0.07 & 0.07 \\
\hline Other Amphipoda & 1.3 & 0.02 & 0.03 & 8.5 & 1.9 & 0.5 \\
\hline Penaeidae & 4.7 & 0.2 & 0.1 & 1.5 & 0.2 & $<0.01$ \\
\hline Lucifer & 18.4 & 2.8 & 6.7 & 9.5 & 3.7 & 0.8 \\
\hline Caridea & 57.0 & 19.9 & 9.2 & 26.1 & 12.3 & 1.3 \\
\hline Other Natantidea & 0.3 & $<0.01$ & $<0.01$ & 0.5 & $<0.01$ & $<0.01$ \\
\hline Thalassinidae & 0.3 & $<0.01$ & $<0.01$ & - & - & - \\
\hline Other Anomura & 11.0 & 0.3 & 2.0 & - & - & - \\
\hline Brachyura larvae & 83.5 & 9.5 & 14.9 & 52.8 & 5.5 & 1.0 \\
\hline Other Crustacea & 11.0 & 7.0 & 0.2 & 22.6 & 7.8 & 0.5 \\
\hline \multicolumn{7}{|l|}{ Pisces } \\
\hline Teleostei larvae & 63.3 & 45.3 & 6.7 & 10.6 & 4.6 & 0.1 \\
\hline Teleostei eggs & 1.6 & 0.04 & 0.07 & 2.0 & 0.02 & 0.02 \\
\hline
\end{tabular}

Calanoid copepods and chaetognaths were negatively selected ( $\mathrm{p}<0.05$ and $\mathrm{p}<0.01$ respectively) in terms of both weight and numbers. Chaetognaths were not eaten at all, despite their relative abundance in the zooplankton. Four other prey taxa - Lucifer, Caridea, Brachyura and teleost larvae contributed significantly more by weight to the diet of Herklotsichthys quadrimaculatus than to the zooplankton biomass. Only Brachyura and teleost larvae were eaten in greater numbers than they occurred in the plankton $(p<0.05)$.

The proportion in the diet of the 4 most important prey taxa changed seasonally (Fig. 3). In both years sampled, calanoids were the main prey in March. Caridea were the main prey during August to January in 1990 and teleosts in February 1991.

The diel feeding pattern of Herklotsichthys quadrimaculatus also showed considerable variation (Fig. 4). The number of Caridea, Brachyura and teleosts eaten peaked during the early night (22:00 h) when fish started to feed. Few calanoids were taken despite their relative abundance at this time (Fig. 4). They were eaten in greater numbers in the early morning, digestion had not started. The 7 major prey taxa during both periods had similar relative importance (by weight) except Calanoida and Teleostei (Table 2). During the day the proportion of calanoids in the diet increased while the number and weight of teleost larvae, carideans and brachyurans decreased ( $p<0.05$; Table 2).

\section{Prey selectivity}

\section{Prey type}

The 8 most important nocturnal zooplankton taxa (those that comprised more than $10 \%$ of total zooplankton on at least 1 sampling occasion) were examined to assess whether they were selectively eaten (Table 3). Six taxa were eaten in significantly different proportions from their occurrence in the plankton.
Table 3. Herklotsichthys quadrimaculatus. Results of Wilcoxon signed rank tests on prey selectivity during nighttime feeding by herring in Kiribati. Calculations are based on the number of individuals and weight of the 8 principal zooplankton types found in the water column (--: negative selection, $p<0.01$; - negative selection, $p<0.05 ;+$ : positive selection, $p<0.05$; NS: not significant). Sample sizes represent the number of occasions that these taxa occurred in both the diet and the zooplankton

\begin{tabular}{|lccc|}
\hline Prey categories & Sample size & Weight & Numbers \\
\hline Polychaeta & 4 & NS & NS \\
Calanoida & 8 & - & - \\
Hyperiidae & 6 & NS & NS \\
Lucifer & 4 & + & NS \\
Caridea & 8 & + & NS \\
Brachyura & 8 & + & + \\
Chaetognath & 8 & - & - \\
Teleostei & 8 & + & + \\
\hline
\end{tabular}



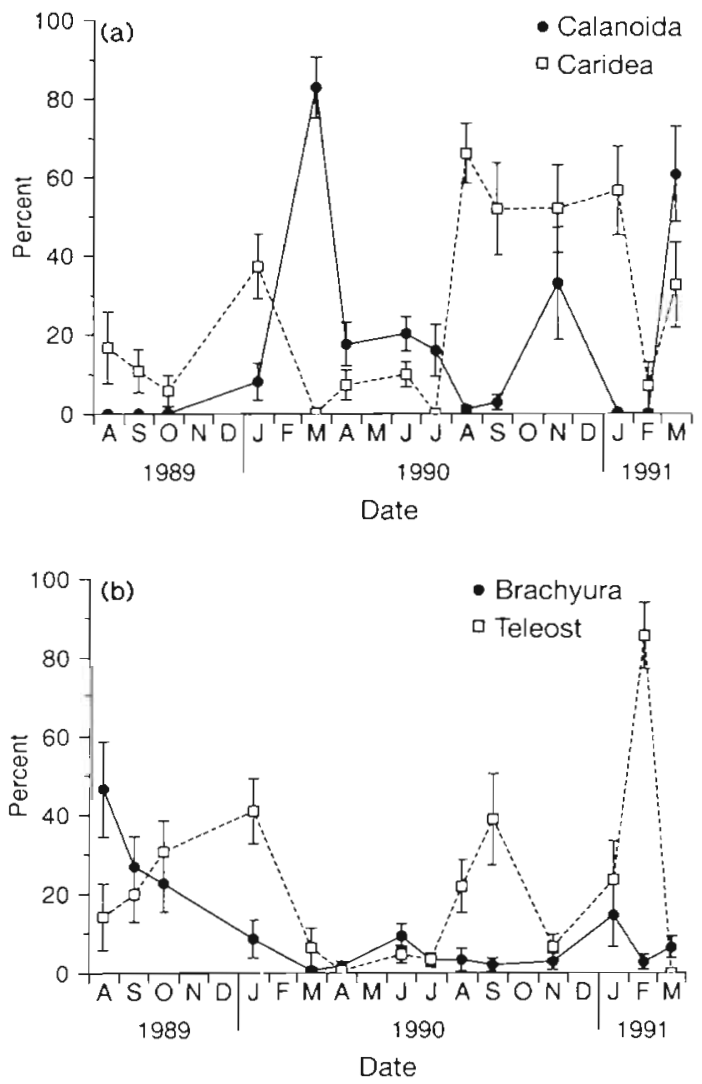

Fig. 3. Herklotsichthys quadrimaculatus. Seasonal changes in the percentage contribution by weight to the diet of herring by (a) Calanoida and Caridea, and (b) Brachyura and Teleostei
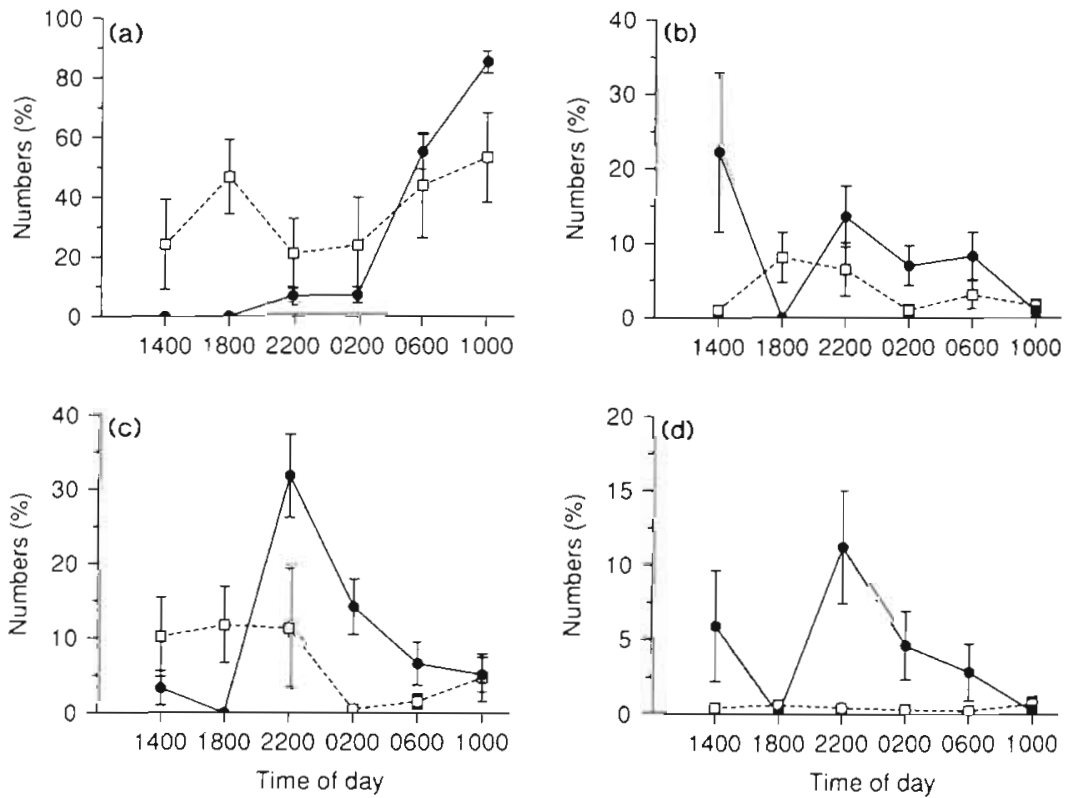

Fig. 4. Herklotsichthys quadrimaculatus. Diel changes in the percent contribution by numbers ( $\pm 95 \%$ confidence limits) of (a) Calanoida, (b) Caridea, (c) Brachyura and (d) Teleostei to the diet of herring (•) and zooplankton ( $\square$ ) when their density was highest and the consumption of preferred prey declined (Fig. 5). Densities of the $3 \mathrm{im}$ portant crustacean taxa peaked between 04:00 and 08:00 h with a smaller peak around sunset (Fig. 5). The densities of teleost larvae did not vary much throughout the day but, like other taxa, were lowest during the afternoon.

The diets of male and female Herklotsich thys quadrimaculatus did not differ in terms of the proportions of the 7 major prey taxa eaten each month (ANOVA: $p>0.4$ in all cases). However, there were ontogenetic differences between the sexes in the proportion of other prey taxa eaten (Fig. 6). Large female $H$. quadrimaculatus ate significantly more Polychaeta and Caridea than did males, and significantly fewer Brachyura ( $p<$ 0.05 in all cases). Young male $H$. quadrimaculatus ate more Calanoida than did females, and their consumption declined drastically as they approached sexual maturity (70 mm) (Fig. 6). This length class also had a significantly greater proportion of teleosts in their diet than did smaller fish.

\section{Prey size}

The mean minimum width of the 5 prey taxa selectively eaten by Herklotsichthys quadrimaculatus often differed from the mean width of that prey in the plankton (Table 4). The narrowest Caridea and Calanoida in the diet were much broader than those in the plankton $(\mathrm{p}<0.01)$, despite Calanoida being negatively selected. In contrast, Lucifer were smaller $(\mathrm{p}<0.01)$. The minimum widths of Brachyura and teleosts in the diet were significantly larger than the mean size in the plankton $(\mathrm{p}<0.05)$.

The mean width of 3 of the prey taxa that were selectively eaten changed throughout the day in the plankton (Fig. 7). Only small carideans were caught in the water column during daylight plankton hauls, while larger ones were found between midnight and 04:00 h. However, the width of carideans in the diet of Herklotsichthys quadrimaculatus was greater in fish collected during the day, although their density was lower (Figs. $5 \&$ 7). The widths of Brachyura and teleosts were significantly greater in samples collected between 16:00 and 20:00 h than in samples collected at other times (Fig. 7). 

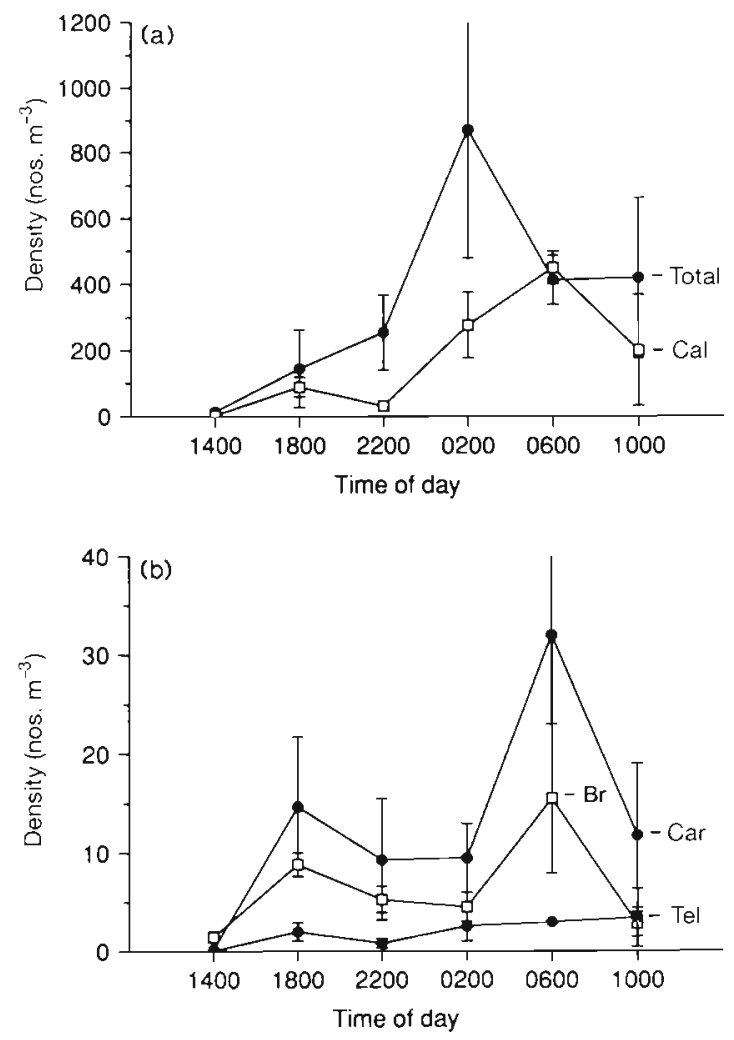

Fig. 5. Diel changes in the mean density $( \pm 95 \%$ confidence limits) of (a) total zooplankton and Calanoida, and (b) Caridea, Brachyura and Teleostei

Fish length and prey width or volume of 5 prey taxa were weakly, but significantly, related $\left(\mathrm{r}^{2}=0.04\right.$ to 0.06; $p<0.05$ in all cases). There was a positive linear relationship between fish length and prey volume for Calanoida, Hyperiidae, Mysidae, Brachyura and Teleostei. Prey width was less related to fish length than was prey volume $\left(\mathrm{r}^{2}<0.04 ; \mathrm{p}<0.05\right.$ in all cases $)$, but there was a positive relationship for Mysidae, Brachyura and Teleostei.

\section{Energetics}

The energy contents of tissues preserved in formalin and fresh tissues were the same $(22.6 \pm 0.5$ and $23.0 \pm$ $0.4 \mathrm{~kJ} \mathrm{~g}^{-1}$ dry wt for fixed tissues and fresh tissues respectively of female Herklotsichthys quadrimaculatus; $t$-test: $\mathrm{df}=59, \mathrm{p}>0.35$ ). This enabled both fixed and fresh fish to be used for calorimetry. When data were combined, there were no significant differences in the energy content of liver, gonad or muscle of female $H$. quadrimaculatus in each of the 5 stages of gonad development ( $p>0.2)$, nor were there any differences between stages of gonad development in the energy content of each tissue $(p>0.5)$ (Table 5). The data were therefore combined to give an overall mean energy value for female $H$. quadrimaculatus of $22.7 \pm 0.3 \mathrm{~kJ} \mathrm{~g}^{-1}$. The energy content of the tissues of male $H$. quadrimaculatus did not differ: the overall mean energy content was $22.9 \pm 0.2 \mathrm{~kJ} \mathrm{~g}^{-1}$.

The reported energy contents of the major zooplankton taxa ranged from 13.04 to $21.88 \mathrm{~kJ} \mathrm{~g}^{-1}$ (Table 6). Teleost larvae and carideans had the highest values, although the energy content was also high in most crustacean taxa. The exception was Brachyura, which had the lowest energy content in most studies.

The mean daily energy intake of Herklotsichthys quadrimaculatus varied seasonally during the study (Fig. 8a). Intake was highest during SeptemberOctober and February-March. The mean energy content of the liver varied less and was not related to mean dietary intake $\left(\mathrm{r}^{2}=0.01, \mathrm{p}<0.77 ; \mathrm{N}=18\right)$. However, it was significantly related to mean gonad energy content $\left(r^{2}=0.22, p<0.05 ; N=20\right)$. Gonad energy content varied seasonally peaking in November 1989, July 1990 and April 1991 (Fig. 8c), but was negatively related to mean energy intake $\left(\mathrm{r}^{2}=-0.31, \mathrm{p}<0.05 ; \mathrm{N}=20\right)$.
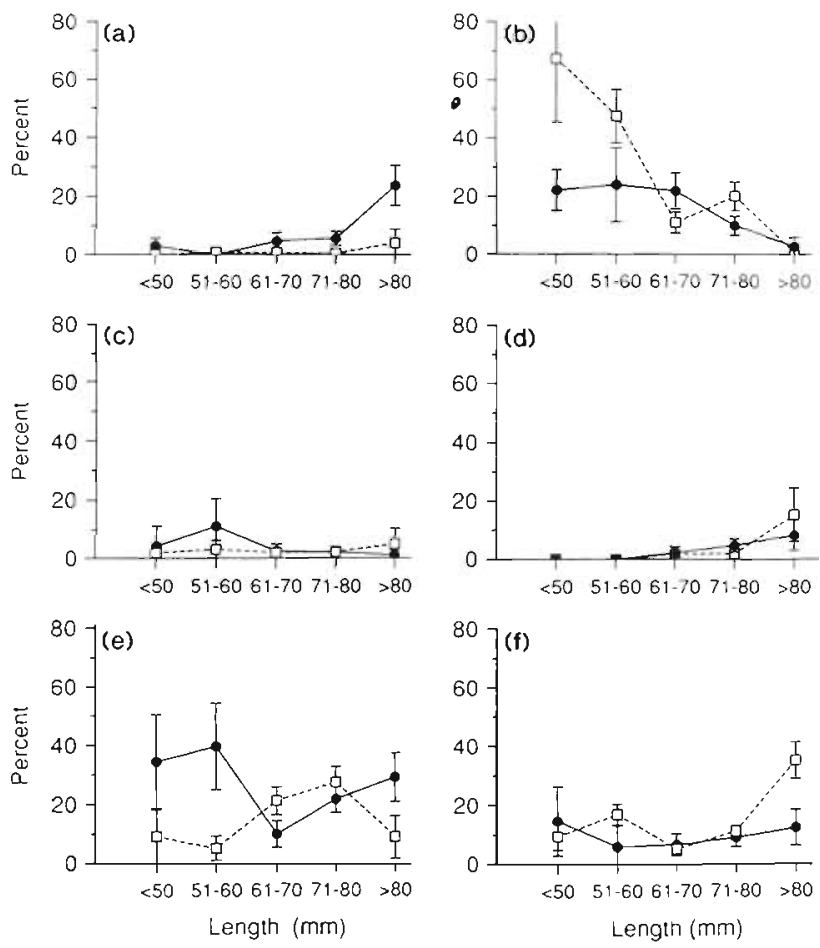

Fig. 6. Herklotsichthys quadrimaculatus. Ontogenetic changes in the percent contribution $( \pm 95 \%$ confidence limits) of (a) Polychaeta (b) Calanoida, (c) Hyperidae, (d) Lucifer, (e) Caridea, (f) Brachyura and (g) Teleostei to the diet of male ( $\square$ ) and female ( $\mathbf{a})$ herring

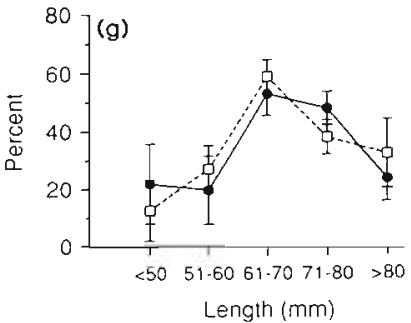


Table 4. Herklotsichthys quadrimaculatus. Mean width ( $\pm \mathrm{SE}$ ) and range of the minimum size of 5 prey types eaten by herring in Kiribati that were positively or negatively selected (see Table 3 ) and their mean width ( \pm SE) and range in the zooplankton

\begin{tabular}{|c|c|c|c|c|c|c|c|c|c|}
\hline \multirow[t]{2}{*}{ Prey } & \multirow[t]{2}{*}{ Site } & \multirow[t]{2}{*}{ Date } & \multirow[t]{2}{*}{ Time } & \multicolumn{3}{|c|}{ Diet } & \multicolumn{3}{|c|}{ Zooplankton } \\
\hline & & & & Mean $\pm S E$ & Range & $N$ & Mean $\pm S E$ & Range & $\mathrm{N}$ \\
\hline \multirow[t]{8}{*}{ Calanoida } & Butaritari & 11 Dec 1990 & $04: 00$ & 0 & 0 & 0 & $0.38 \pm 0.01$ & $0.16-0.84$ & 109 \\
\hline & & 11 Jan 1991 & $21: 30$ & $0.51 \pm 0.04$ & $0.40-0.76$ & 8 & $0.52 \pm 0.02$ & $0.16-0.88$ & 82 \\
\hline & & 14 Feb 1991 & $20: 30$ & 0 & 0 & 0 & $0.29 \pm 0.01$ & $0.16-0.40$ & 99 \\
\hline & Abaiang & 30 Jun 1990 & $02: 30$ & $0.68 \pm 0.03$ & $0.48-0.80$ & 11 & $0.42 \pm 0.02$ & $0.20-0.84$ & 103 \\
\hline & & 17 Aug 1990 & $04: 30$ & $0.66 \pm 0.02$ & $0.48-0.76$ & 11 & $0.28 \pm 0.01$ & $0.20-0.68$ & 90 \\
\hline & Tarawa & O6 Jun 1990 & $09: 00$ & $0.49 \pm 0.03$ & $0.28-0.80$ & 18 & $0.75 \pm 0.01$ & $0.24-1.0$ & 181 \\
\hline & & 15 Aug 1990 & $04: 00$ & $0.86 \pm 0.04$ & $0.60-1.0$ & 10 & $0.25 \pm 0.01$ & $0.12-0.64$ & 105 \\
\hline & Abemama & 12 Jun 1990 & $09: 30$ & 0 & 0 & 0 & $0.32 \pm 0.002$ & $0.28-0.40$ & 121 \\
\hline \multirow[t]{4}{*}{ Lucifer } & Butaritari & 11 Dec 1990 & $04: 00$ & 0 & 0 & 0 & $0.61 \pm 0.002$ & $0.28-1.20$ & 93 \\
\hline & Abaiang & 30 Jun 1990 & $02: 30$ & 0 & 0 & 0 & $1.90 \pm 0.15$ & $0.80-3.60$ & 22 \\
\hline & & 17 Aug 1990 & $04: 00$ & $0.62 \pm 0.10$ & $0.52-0.72$ & 2 & $0.91 \pm 0.04$ & $0.44-1.16$ & 21 \\
\hline & Abemama & 12 Jun 1990 & $09: 30$ & $0.80 \pm 0.09$ & $0.60-1.0$ & 11 & $1.79 \pm 0.05$ & $0.80-3.00$ & 127 \\
\hline \multirow[t]{3}{*}{ Caridea } & Butaritari & 06 Jun 1990 & 09:00 & $1.40 \pm 0.0$ & 1.40 & 1 & $0.45 \pm 0.01$ & $0.32-0.80$ & 100 \\
\hline & Abaiang & 30 Jun 1990 & $02: 30$ & $1.70 \pm 0.38$ & $0.72-3.32$ & 8 & $0.56 \pm 0.06$ & $0.32-2.80$ & 42 \\
\hline & Abemama & 12 Jun 1990 & $09: 30$ & $2.52 \pm 0.0$ & 2.52 & 3 & $0.41 \pm 0.01$ & $0.20-0.88$ & 109 \\
\hline \multirow[t]{8}{*}{ Brachyura } & Butaritari & $11 \mathrm{Dec} 1990$ & $04: 00$ & $1.55 \pm 0.40$ & $0.84-2.28$ & 5 & $1.01 \pm 0.09$ & $0.40-1.40$ & 19 \\
\hline & & $11 \mathrm{Jan} 1991$ & $21: 30$ & $1.17 \pm 0.07$ & $0.76-1.68$ & 17 & $0.55 \pm 0.05$ & $0.24-1.32$ & 26 \\
\hline & & 14 Feb 1991 & $20: 30$ & $1.24 \pm 0.10$ & $0.48-1.72$ & 15 & $0.47 \pm 0.01$ & $0.40-0.56$ & 16 \\
\hline & Abaiang & 30 Jun 1990 & $02: 30$ & $0.43 \pm 0.03$ & $0.32-0.60$ & 12 & $0.83 \pm 0.10$ & $0.20-1.60$ & 19 \\
\hline & & 17 Aug 1990 & $04: 00$ & $0.73 \pm 0.08$ & $0.20-1.20$ & 14 & $1.35 \pm 0.02$ & $0.24-1.64$ & 73 \\
\hline & Tarawa & 06 Jun 1990 & 09:00 & $1.31 \pm 0.10$ & $0.80-2.0$ & 15 & $0.67 \pm 0.04$ & $0.40-1.48$ & 37 \\
\hline & & 15 Aug 1990 & 04:00 & $0.82 \pm 0.06$ & $0.40-1.20$ & 10 & $0.49 \pm 0.14$ & $0.24-1.04$ & 6 \\
\hline & Abemama & 12 Jun 1990 & $09: 30$ & $0.81 \pm 0.05$ & $0.20-1.20$ & 22 & $0.82 \pm 0.06$ & $0.28-1.68$ & 38 \\
\hline \multirow[t]{4}{*}{ Teleostei } & Butaritan & 11 Dec 1990 & $04: 00$ & $1.34 \pm 0.08$ & $1.20-1.64$ & 4 & $1.82 \pm 0.18$ & $1.08-4.96$ & 21 \\
\hline & Abaiang & 30 Jun 1990 & $02: 30$ & $1.25 \pm 0.18$ & $0.40-1.68$ & 7 & $1.14 \pm 0.19$ & $0.20-2.40$ & 15 \\
\hline & Tarawa & 06 Jun 1990 & $09: 00$ & 0 & 0 & 0 & $1.24 \pm 0.03$ & $1.12-1.44$ & 10 \\
\hline & Abemama & 12 Jun 1990 & $09: 30$ & $1.64 \pm 0.04$ & $1.60-1.68$ & 2 & $0.37 \pm 0.01$ & $0.20-0.60$ & 77 \\
\hline
\end{tabular}
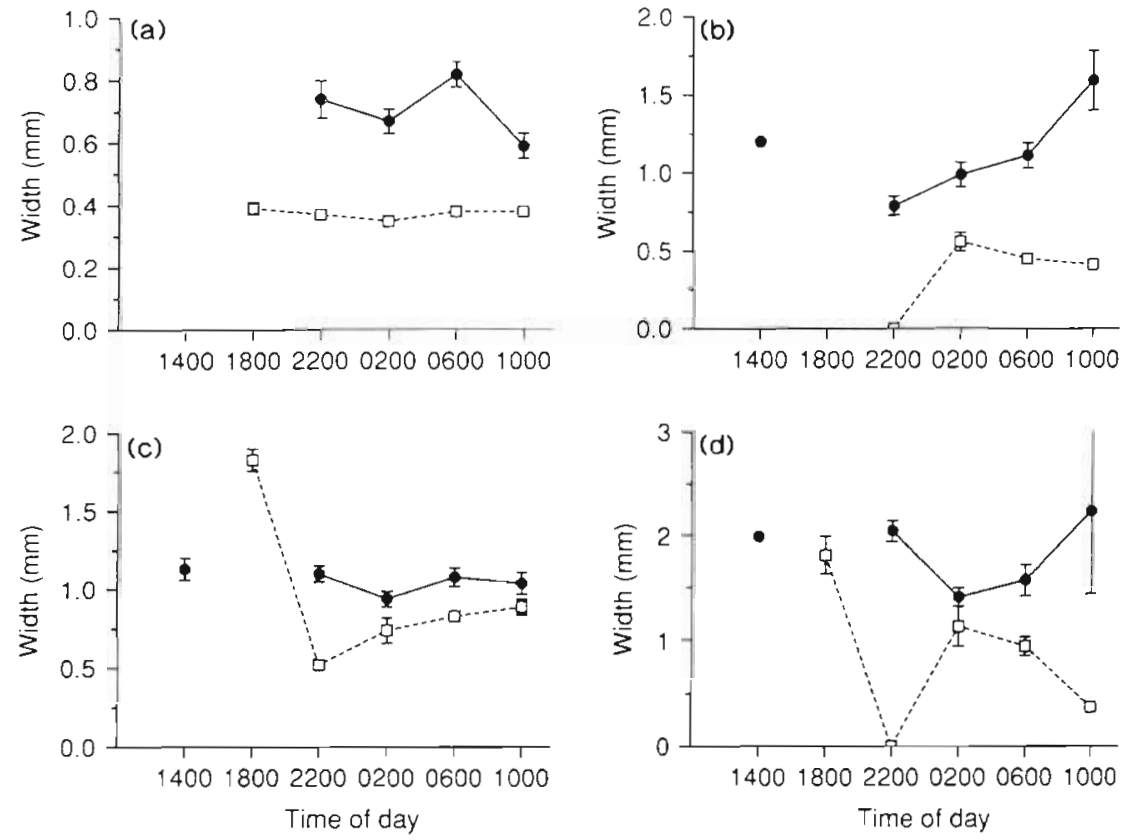

Fig. 7. Herklotsichthys quadrimaculatus. Diel changes in the mean minimum prey width $( \pm 95 \%$ confidence limits) in the diet ( $\bullet$ and mean width in the zooplankton (c) of (a) Calanoida, (b) Caridea, (c) Brachyura and (d) Teleostei 
Table 5. Herklotsichthys quadrimaculatus. Mean length, GSI and calorific content $\left(\mathrm{kJ} \mathrm{g}^{-1} \pm\right.$ SE dry wt) of gonad, liver and muscle of herring in different stages of gonad maturity

\begin{tabular}{|c|c|c|c|c|c|c|c|}
\hline Gonad stage & Sex & Length $\pm \mathrm{SE}$ & $\mathrm{GSI} \pm \mathrm{SE}$ & Gonad & Liver & Muscle & $N$ \\
\hline Stage 2 & $\mathrm{~F}$ & $83.5+1.4$ & $0.22 \pm 0.02$ & $21.6 \pm 0.6$ & $22.9 \pm 0.6$ & $22.2 \pm 0.3$ & 15 \\
\hline Stage 3 & F & $76.8 \pm 2.6$ & $2.32 \pm 0.18$ & $22.1 \pm 0.5$ & $23.0 \pm 0.5$ & $21.9 \pm 0.2$ & 5 \\
\hline Stage 4 & $\mathrm{~F}$ & $71.2 \pm 0.8$ & $3.24 \pm 0.18$ & $22.6 \pm 0.7$ & $21.9 \pm 0.4$ & $22.9 \pm 0.5$ & 6 \\
\hline Stage 5 & $\mathrm{~F}$ & $75.1 \pm 2.2$ & $5.53 \pm 0.39$ & $22.5 \pm 0.5$ & $22.2 \pm 0.3$ & $21.8 \pm 0.3$ & 9 \\
\hline Stage 6 & $\mathrm{~F}$ & $79.3 \pm 1.8$ & $1.28 \pm 0.01$ & $22.3 \pm 0.7$ & $23.5 \pm 0.8$ & $23.5 \pm 0.6$ & 7 \\
\hline All & $\mathrm{M}$ & $74.7 \pm 0.4$ & $0.58 \pm 0.03$ & $22.9 \pm 0.9$ & $23.0 \pm 0.3$ & $22.6 \pm 0.3$ & 24 \\
\hline
\end{tabular}

Mean daily energy intake each month was also compared with both the proportion of spent fish and the spawning frequency (using data from Milton et al. 1993b), but no significant relationships were found $\left(\mathrm{r}^{2}=0.04 ; \mathrm{p}>0.59, \mathrm{~N}=16\right.$ and $\mathrm{r}^{2}=0.06 ; \mathrm{p}>0.35$, $\mathrm{N}=16$, respectively).

\section{DISCUSSION}

The diet of Herklotsichthys quadrimaculatus in Kiribati was similar to that in other parts of its range (Marichamy 1970, Williams \& Clarke 1983). It is mainly nocturnal, feeding on pigmented or opaque zooplankters (crustaceans and teleost larvae) as do other tropical particulate- feeding zooplanktivores (Nakamura \& Wilson 1970, Hobson \& Chess 1973, 1978. Clarke 1980, Douglas 1982, Milton et al. 1990a).

Herklotsichthys quadrimaculatus is strongly selective in its diet, so is unlikely to filter feed under normal conditions. The temperate herring Clupea harengus feeds by biting when prey density is low and by filtering when it is high; filtering is energetically more

Table 6. Herklotsichthys quadrimaculatus. Energy content of prey taxa of herring that were used in energetic analysis

\begin{tabular}{|lcl|}
\hline Taxa & $\begin{array}{c}\text { Energy content } \\
\text { (kJ g }{ }^{-1} \text { dry wt) }\end{array}$ & Source \\
\hline Polychaeta & 18.57 & Whitfield (1980) \\
Bivalvia & 20.08 & Blaber (1979) \\
Other Gastropoda & 17.80 & Thayer et al. (1973) \\
Calanoida (Acartia) & 14.49 & Blaber (1979) \\
Ostracoda & 15.48 & Whitfield (1980) \\
Mysidacea & 19.19 & Blaber (1979) \\
Isopoda & 14.62 & Whitfield (1980) \\
Amphipoda & 15.51 & Thayer et al. (1973) \\
Caridea & 20.20 & Blaber \& Bulman (1987) \\
Other natant Decapoda & 19.80 & Thayer et al. (1973) \\
Anomura & 19.24 & Thayer et al. (1973) \\
Brachyura & 13.04 & Blaber (1979) \\
Other Crustacea & 17.40 & Thayer et al. (1973) \\
Teleostei larvae & 21.88 & Thayer et al. (1973) \\
& & \\
\hline
\end{tabular}
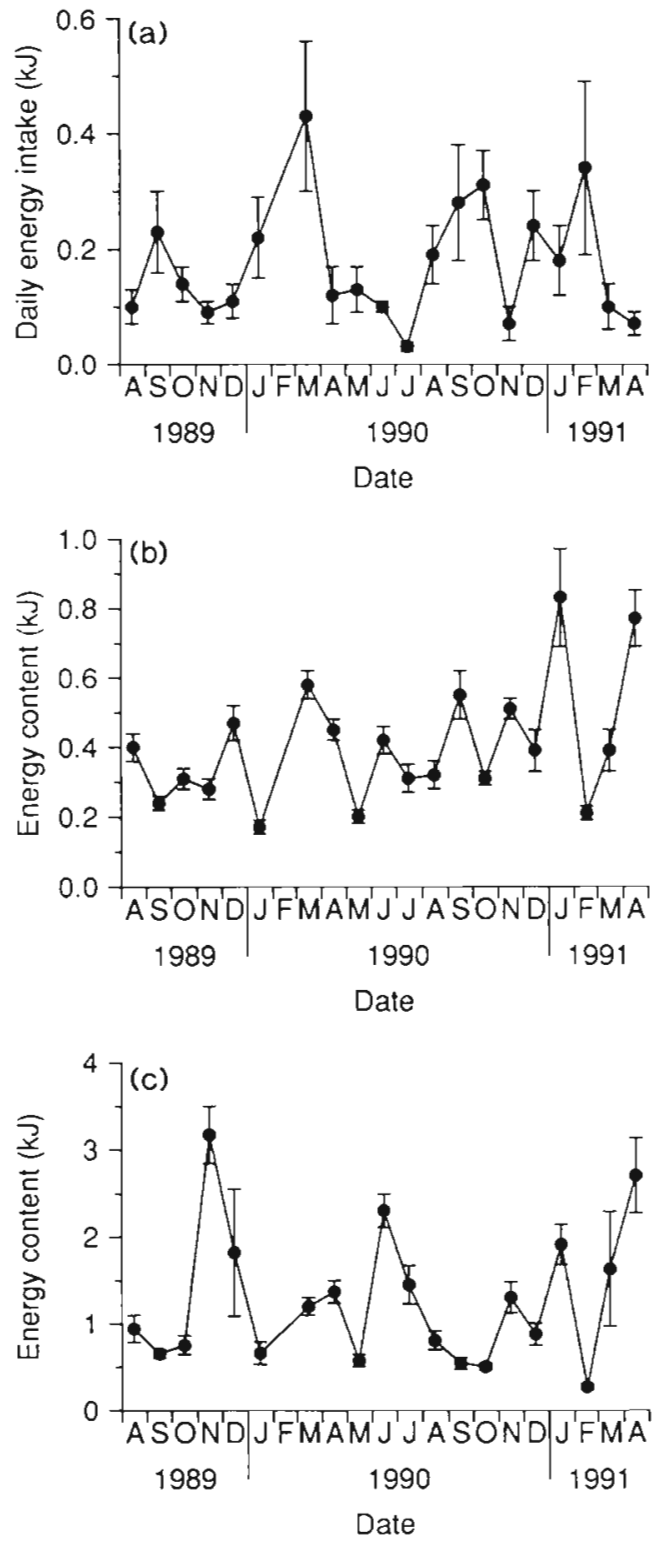

Fig. 8. Herklotsichthys quadrimaculatus. Seasonal changes in (a) mean daily energy intake ( $\pm 95 \%$ confidence limits), (b) energy content of the liver and (c) gonad of female herring 
costly (Gibson \& Ezzi 1985, 1992). Switching between feeding modes is common in many planktivorous fish species (Leong \& $O^{\prime}$ Connell 1969, O'Connell \& Zweifel 1972, Janssen 1976); this probably also relates to the relative profitability of each method (Crowder 1985). At normal prey densities (maximum of $8001^{-1}$ in Kiribati) particulate-feeding fish would have a higher energy intake than filter feeders (Gibson \& Ezzi 1992, Sanderson \& Cech 1992).

Herklotsichthys quadrimaculatus selectively fed on larger individuals of larger zooplankton taxa (e.g. Caridea and teleost larvae) or larger individuals of the more abundant zooplankters (e.g. Brachyura). Peak feeding intensity did not coincide with highest densities of either preferred prey or total zooplankton: the fish began feeding after dark, while zooplankton densities were higher around dusk and dawn. H. quadrimaculatus school in shallow water adjacent to coral reefs during the day (Williams \& Clarke 1983, Conand et al. 1988), when their visual predators are active, only dispersing to feed when light levels fall. This pattern differs from that of the smaller tropical clupeoids Encrasicholina sp. and Spratelloides sp., which feed in a density-dependent manner, often throughout the day, on common zooplankters (Milton et al. 1990a). These smaller species prey selectively on only some of the more visible prey, such as pigmented hyperiid amphipods.

Selective predation on larger, high-energy prey was most apparent in mature Herklotsichthys quadrimaculatus (>65 mm). Maturing fish increased their intake of high-calorie teleost larvae dramatically, which could have enabled them to develop gonadal material without slowing their somatic growth. This would be of selective advantage to short-lived species such as $H$. quadrimaculatus, as they become sexually mature in less than 5 mo (Milton et al, 1993).

Immature male Herklotsichthys quadrimaculatus also ate more calanoids and fewer carids than immature females $(<60 \mathrm{~mm}$ ) and both ate more of these prey than adults of the same sex. These differences may be related to the differential spatial distribution of the sexes that is common in tropical clupeoids (Nakamura \& Wilson 1970, Williams \& Clarke 1983, Milton et al 1990b). Williams \& Clarke (1983) found that female $H$. quadrimaculatus predominated in samples collected during the day in shallow water in Hawaii, while males were more catchable at night around underwater lights in the deeper parts of the lagoon. They suggested that these differences in distribution were related to spawning as spawning schools of pelagic clupeoids that spawn at night are dominated by males (Hunter \& Goldberg 1980). This is unlikely to cause the differences in diet we found, as there were few differences in the relative proportion of major prey in the diets of mature male and female $H$. quadrimaculatus. Our results suggest that immature fish of each sex have a differential preference for particular prey in mixed schools, or that the sexes are segregated and feed in different areas.

There were seasonal and diel shifts in the relative importance of major prey in the diet of Herklotsichthys quadrimaculatus. Carideans and teleost larvae were more important in the diet during the north-west monsoon (August to February) and were eaten mainly at night. Predation on calanoid copepods peaked during March in both years of the study. These prey were eaten during daylight, when their densities are high in shallow waters. H. quadrimaculatus usually form dense schools in shallow water during the day (Marichamy 1970, Williams \& Clarke 1983). Marichamy (1970) suggested that the feeding intensity of $H$. quadrimaculatus in the Andaman Islands increased during the prespawning period. However, in Kiribati $H$. quadrimaculatus spawned throughout the year, with increased spawning frequency during the 2 monsoon periods (Milton et al. 1994). Daylight feeding on calanoids may only occur when copepod densities are high in shallow waters. It was not related to periods of increased spawning frequency or more intensive spawning.

The energetic costs of spawning have been examined in few clupeids, none of which are tropical species. Hunter \& Leong (1981) found that female Engraulis mordax expended about $52 \%$ of the energy contents of their ovaries in producing each batch of eggs. The energy content of Herklotsichthys quadrimaculatus ovaries was similar to that of E. mordax, as was the egg dry weight (Milton et al. 1994). Using the approach of Hunter \& Leong (1981), we found that an averagesized batch of eggs (ca 2000) would contain $1.46 \mathrm{~kJ}$, which represented $62 \%$ of the energy content of the ovary. This gives a daily energy cost of spawning during peak spawning of $0.73 \mathrm{~kJ}$ (spawning every $2 \mathrm{~d}$ ), as compared to $0.63 \mathrm{~kJ} \mathrm{~d}^{-1}$ for E. mordax spawning once a week. These figures suggest that during peak spawning, $H$. quadrimaculatus must rely on energy reserves, stored either in the liver or as fat, to support this level of reproduction. Liver mass declined in spent $H$. quadrimaculatus (Milton et al. 1994) and the energy content of the liver was positively related to the energy content of gonads, which suggests that fish need to be in good nutritional condition to spawn.

Daily energy intake was negatively related to gonadal energy content in female Herklotsichthys quadrimaculatus. This is probably not due to a physiological response but due to the body cavity being smaller just before spawning; prior to spawning the ovary fills over two-thirds of the cavity.

The daily energy intake of Herklotsichthys quadrimaculatus was not related to spawning frequency nor 
to the proportion of spent fish each month. Seasonal changes in the relative importance in the diet of preferred prey probably reflects differences in abundance rather than actual dietary shifts towards higher-energy prey during periods of intense spawning, as the proportion of $H$. quadrimaculatus spawning in Kiribati during most months was similar (Milton et al. 1994).

If the spawning activity of each fish relies on its nutritional status, spawning is unlikely to be synchronous. Recent studies of tropical clupeids, including Herklotsichthys quadrimaculatus, have found that spawning in all species is asynchronous and not strongly related to any proximate cues (Wright 1990 , Milton \& Blaber 1991, Milton et al. 1994). Spawning in these species appears to be related both to dietary intake and to the nutritional status of the fish, as has been hypothesised for the temperate herring Clupea harengus (Aneer 1985, Rajasilta 1992). Individual $H$. quadrimaculatus maximize their dietary intake and spawning capacity by feeding selectively on large, high-energy prey. They also use energy stored in the liver for developing gonadal tissue, which could enable them to spawn even during periods when energy intake may be low. This strategy would offset short-term prey fluctuations and ensure that the fish spawn the greatest number of eggs that could encounter favourable conditions for survival (Armstrong \& Shelton 1990).

Acknowledgements. We thank staff of the Kiribati Fisheries Division for their support during the fieldwork in this study. We also thank Melissa White and Michael O'Neill for assisting in the laboratory analyses, and Kevin Warburton and Tim Davis for making constructive comments on earlier drafts of the manuscript. This work was funded by the Australian Council for International Agricultural Research (PN 9003).

\section{LITERATURE CITED}

Aneer, G. (1985). Some speculation about the Baltic herring (Clupea harengus membras) in connection with the eutrophication of the Baltic Sea. Can. J. Fish. Aquat. Sci. 42 (Suppl. 1): 83-90

Armstrong, M. J., Shelton, P. A. (1990). Clupeoid life-history styles in variable environments. Environ. Biol. Fish. 28: 77-85

Baker, J. R. (1966). Cytological techniques. Methuen, London

Blaber, S. J. M. (1979). The biology of filter feeding teleosts in Lake St Lucia, Zululand. J. Fish Biol. 15: 37-59

Blaber, S. J. M., Bulman, C. M. (1987). Diets of fishes of the upper continental slope of eastern Tasmania: content, calorific values, dietary overlap and trophic relationships. Mar. Biol. 95: 345-356

Blaxter, J. H. S., Hunter, J. R. (1982). The biology of clupeoid fishes. In: Blaxter, J. H. S., Russell, F. S., Yonge, M. (eds.) Advances in marine biology, Vol. 20. Academic Press, London, p. 1-223

Boggs, C. H. (1991). Bioenergetics and growth of northern anchovy Engraulis mordax. Fish. Bull. U.S. 89: 555-566
Brett, J. R., Groves, T. D. D. (1979). Physiological energetics. In: Hoar, W. S., Randall, D. J., Brett, J. R. (eds.) Fish physiology, Vol. 8. Academic Press, New York, p. 279-352

Clarke, $\Upsilon$ A. (1980). Diets of fourteen species of vertically migrating mesopelagic fishes in Hawaiian waters. Fish. Bull. U.S. 78: 619-640

Conand, F., Boely, T., Petıt, D. (1988). Spatial distribution of small pelagic fish in the lagoon of New Caledonia. Proc. 6th int. coral Reef Symp. 2: 65-69

Crowder, L. B. (1985). Optimal foraging and feeding mode shifts in fishes. Environ. Biol. Fish. 12: 57-62

Cushing, D. H. (1967). The grouping of herring populations. J mar. biol. Ass. U.K. 47: 193-208

Cushing, D. H. (1975). Marine ecology and fisheries. Cambridge Univ. Press, Cambridge

Dayaratne, P., Gjosaeter, J. (1986). Age and growth of four Sardinella species from Sri Lanka. Fish. Res. 4: 1-33

Douglas, W. A. (1982). The feeding ecology of cardinalfish (Pisces: Apogonidae) at One Tree Reef. M.Sc. thesis, Univ. Sydney

Gibson, R. N., Ezzi, I. A. (1985). Effect of particle concentration on filter-and particulate-feeding in the herring Clupea harengus. Mar. Biol. 88: 109-116

Gibson, R. N., Ezzi, I. A. (1992). The relative profitability of particulate- and filter-feeding in the herring, Clupea harengus. J. Fish Biol. 40: 577-590

Hardy, R., Mackie, P. (1969). Seasonal variation in some of the lipid components of sprats (Sprattus sprattus). J. Sci. Fd Agric. 20: 193-198

Hayashi, K., Takagi, T (1977). Seasonal variation in lipids and fatty acids of sardine, Sardinops melanosticta. Bull. Fac. Fish. Hokkaido Univ. 28: 83-94

Hayashi, K., Takagi, T (1978). Seasonal variation in lipids and fatty acids of Japanese anchovy, Engraulis japonica. Bull. Fac. Fish. Hokkaido Univ. 29: 38-47

Henderson, R. J., Almatar, S. M. (1989). Seasonal changes in the lipid composition of herring (Clupea harengus) in relation to gonad maturation. J. mar. biol. Ass. U.K. 69: $323-334$

Henderson, R. J., Sargent, J. R., Hopkins, C. C. E. (1984) Changes in the content and fatty acid composition of lipid in an isolated population of capelin Mallotus villosus during sexual maturation and spawning. Mar. Biol. 78 $255-263$

Hobson, E. S., Chess, J. R. (1973). Feeding oriented movements of the atherinid fish Pranesus pinguis at Majuro Atoll, Marshall Islands. Fish. Bull U.S. 71: 777-786

Hobson, E. S., Chess, J. R. (1978). Trophic relationships among fishes and plankton in the lagoon at Enewetak Atoll, Marshall Islands. Fish. Bull. U.S. 76: 133-153

Hunter, J. R., Goldberg, S. R. (1980). Spawning incidence and batch fecundity in northern anchovy Engraulis mordax. Fish. Bull. U.S. 77: 641-652

Hunter, J. R., Leong, R. (1981). The spawning energetics of female northern anchovy Engraulis mordax. Fish. Bull. U.S. $79: 215-230$

Janssen, J. (1976). Feeding modes and prey selection in the alewife (Alosa pseudoharengus). J. Fish. Res. Bd Can. 33: $1972-1975$

Kearney, R. E. (1982). Methods used by the South Pacific Commission for the survey and assessment of skipjack and baitfish resources. Tuna and Billfish Assess. prog. Tech. Rep. 7. South Pacific Commission, Noumea, New Caledonia

Kohler, C. C., Ney, J. J (1982). A comparison of methods for quantitative analysis of feeding selection of fishes. Environ. Biol. Fish. 7: 363-368 
Leong, R. J. H., O'Connell, C. P. (1969). A laboratory study of particulate and filter feeding of the northern anchovy (Engraulis mordax). J. Fish. Res. Bd Can. 26: 557-582

Lewis, A. D. (1990). Tropical south Pacific tuna baitfisheries. In: Blaber, S. J. M., Copland, J. W. (eds.) Tuna baitfish in the Indo-Pacific region. Aust. Coun. int. agr. Res. Proc. 30: $10-21$

Linko, R. R., Kaitaranta, J. K., Vuorela, R. (1985). Composition of the fatty acids in Baltic herring and the available plankton feed. Comp. Biochem. Physiol. 82B: 699-705

Marichamy, R. (1970). Food and feeding habits of the spotted herring, Herklotsichthys punctatus from the Andaman Sea. Indian J. Fish. 17: 159-168

Milton, D. A., Blaber, S. J. M. (1991). Maturation, spawning seasonality, and proximate spawning stimuli of six species of tuna baitfish in the Solomon Islands. Fish. Bull. U.S. 89: $221-237$

Milton, D. A., Blaber, S. J. M., Rawlinson, N. J. F. (1990a). Diet and prey selection of six species of tuna baitfish in three coral reef lagoons in the Solomon Islands. J. Fish Biol. 37: 205-224

Milton, D. A., Blaber, S. J. M., Rawlinson, N. J. F. (1993). Age and growth of three species of clupeid from Kiribati, tropical central south Pacific. J. Fish Biol. 43: 89-108

Milton, D. A., Blaber, S. J. M., Rawlinson, N. J. F. (1994). Reproductive biology and egg production of three species of clupeid in Kiribati, central Pacific. Fish. Bull. U.S. 92(1) (in press)

Milton, D. A., Blaber, S. J. M., Tiroba, G., Leqata, J. L., Rawlinson, N. J. F., Hafiz, A. (1990b). Reproductive biology of Spratelloides delicatulus, S. gracilis and Stolephorus heterolobus from Solomon Islands and Maldives. In: Blaber, S. J. M., Copland, J. W. (eds.) Tuna baitfish in the IndoPacific region. Aust. Coun. int. agr. Res. Proc. 30: 89-99

Nakamura, E. L., Wilson, R. C. (1970). The biology of the Marquesan sardine, Sardinella marquesensis. Pacif. Sci. 24: $359-376$

This article was submitted to the editor
O'Connell, C. P., Zweifel, J. R. (1972). A laboratory study of particulate and filter feeding of the Pacific mackerel, Scomber japonicus. Fish. Bull. U.S. 70: 973-981

Rajasilta, M. (1992). Relationship between food, fat, sexual maturation, and spawning time of Baltic herring (Clupea harengus membras) in the Archipelago Sea. Can. J. Fish. Aquat. Sci. 49: 644-654

Rawlinson, N. J. F., Milton, D. A., Blaber, S. J. M. (1992) Tuna baitfish and the pole-and-line industry in Kiribati. Aust. Coun. int. agr. Res. Tech. Rep. 24: 1-90

Sanderson, S. L., Cech, J. J. Jr (1992). Energetic cost of suspension feeding versus particulate feeding by juvenile Sacramento blackfish. Trans. Am. Fish. Soc. 121: $149-157$

Smith, P. E., Eppley, R. W. (1982). Primary production and the anchovy population in the southern California Bight: comparison of time series. Limnol. Oceanogr. 27: 1-17

Sokal, R. R., Rohlf, F. J. (1981). Biometry, 2nd edn. W. H. Freeman, New York

Thayer, G. W., Schaaf, W. E., Angelovic, J. W., LaCroix, M. W (1973). Calorific measurements of some estuarine organisms. Fish. Bull U.S. 71: 289-296

Townshend, T. J., Wootton, R. J. (1984). Effects of food supply on the reproduction of the convict cichlid, Cichlasoma nigrofasciatum. J. Fish Biol. 24: 91-104

Whitfield, A. K. (1980). A quantitative study of the trophic relationship within the fish community of the Mhlanga estuary, South Africa. Estuar. coast. mar. Sci. 10 . $417-435$

Williams, V. R., Clarke, T A. (1983). Reproduction, growth, and other aspects of the biology of the gold spot herring, Herklotsichthys quadrimaculatus (Clupeidae), a recent introduction to Hawaii. Fish. Bull. U.S. 81: 587-597

Wright, P. J. (1990). The reproductive strategy of Stolephorus heterolobus in the south Java Sea. In: Blaber, S. J. M., Copland, J W. (eds.) Tuna baitfish in the Indo-Pacific region. Aust. Coun. int. agr. Res. Proc. 30: 83-88

Manuscript first received: June 23, 1993

Revised version accepted: October 14, 1993 